\title{
Paul Hanebrink, A Specter Haunting Europe: The Myth of Judeo- Bolshevism, Cambridge, Massachusetts, London, England: Belknap Press of Harvard University Press, 2018.
}

\author{
Zoltán Peterecz
}

Many myths are part of our lives, past and present, and we hardly notice most of them. Paul A. Hanebrink of Rutgers University set out to examine a relatively new historical myth, which, however, has been a force to reckon with ever since it was created: Judeo-Bolshevism. The gist of this myth that was born in the beginning of the twentieth century is that Communism was basically a Jewish conspiracy in order to achieve hegemony in the world, "a transhistorical global conspiracy by Jews to destroy Western civilization." (4) It is no coincidence that the idea first reared its head during World War I. Anti-Semitism had had a long history in Europe, when in 1917, in the wake of the Russian Bolshevik Revolution, a new state ideology appeared on the scene, which denied practically everything that had accumulated in European and North American societies and culture: property rights, individual freedom, religion, etc. Therefore, with the cataclysmic changes during and right after the war, it was relatively easy to make large masses of people believe, both in Europe and the United States, that the root of the trouble was the Jewish communists. And it is enough to think of the events in Hungary or Germany in 1919 to appreciate the magnitude of this question. In the twenty-first century, when due to complex issues nationalism has been on the rise once more, many appear to have found an answer in the familiar vein: anti-Semitism and the accusation of Judeo-Bolshevism. What is more, this new trend is not only palpable in Central and Eastern Europe, where for historical reasons this might be less surprising; these voices can be heard in Western Europe and on the far right in the United States as well.

Hanebrink goes through some periods of the twentieth century and examines in the historical mirror the accusations_-imagined or real_ - of a Judeo-Bolshevist agenda. The inevitable starting point is 1919, when shortly after the seismic shift caused by the Russian Bolsheviks, in the chaos brought on by the end of the world war, in Central Europe-in Germany and Hungary-revolutions appeared in short succession. It is true that many Jewish persons were attracted to the radical ideology and movements, but the reason for this lay in the fact that most of them did not get the chance to fully assimilate in their respective countries. There was political fragmentation among the Jewish people as well, but their presence 
was acutely felt in far left organizations everywhere-sometimes making up the majority. Therefore, those Jews who openly and loudly were disseminating the tenets of Bolshevik ideology made it possible that the Jewry as one could be made the scapegoat for the social pandemonium. The author identifies three antiSemitic beliefs that had been around for centuries: striving for social disharmony, international Jewish conspiracy to the detriment of Christians, and Jewish fanaticism. The revolutionary period, naturally, only heightened and strengthened these fears, and gave a wide enough basis for large multitudes of people to believe in Judeo-Bolshevism as the modern-day equivalent of the Jewish danger.

When the revolutions in East and Central Europe, suitably to their nature, led to excesses and a reign of terror, (imagined) "reality" justified fear that Jews and Bolsheviks wanted to overtake the control in various countries and they were not circumspect as to their means. This fear was married to the old European historical reflex that physical danger is manifested in the shape of barbaric hordes coming from the East-bringing alien and primitive culture with them. The Mongols and later the Turks were the par excellence examples, and Europe had to be defended against their incursion and devastation. This strain of thinking was especially strong in Polish and Hungarian historical mythology. Although it must not be forgotten that when the first tribes of Hungarians appeared in the Carpathian Basin and raided the land west to them, they were judged by the same standard as later Batu Khan's hordes or the Turkish Sultans' armies. "The Bolshevik," writes the author, "was at once a rootless migrant Jew, the sign of an invading horde from the East, and an Asiatic beast." (41) Twentieth-century communist "danger" was similarly perceived by many, and Europe, but especially Central and Eastern Europe, in the wake of the losses in World War I and social uproar, appears to have found the new source of peril in Judeo-Bolshevism. This danger seemed to threaten the whole European order and civilization. Since the fanaticism and messianism of the Jews was well known, fear grew into hysteric proportion at times and places that their country would be ruled by revolution — and the Christian world might be conquered.

Before World War I, in the area of Eastern Europe where Jews were concentrated in larger numbers_-Poland, Russia, Ukraine-pogroms regularly took place. As a result, tens of thousands of poor Jewish people began to move westward. They were the Galician Jews who arrived in Budapest and Vienna, among other places, where they were not welcome, and they were often found to be the scapegoats for shortages of all kinds when war arrived. With the Bolshevik revolution in 1917, the hatred toward the Jews collectively only gained strength when, on account of the Jewish political actors, the "revolutionary-subversive" label was extended generally to the Jewry. With the armistice in November 1918, fights did not cease 
in Central and Eastern Europe-civil wars and revolutions were a typical feature in the region. Hanebrink introduces the Polish, Romanian, and Hungarian examples in order to give an extensive picture of the anti-Judeo-Bolshevist sentiment and steps taken against that perceived danger. All these countries wanted to create a pure nation state, and they propagated this wish at the Paris Peace Conference. Naturally, Jews were not deemed as part of that national image. It seemed good political capital for all the newly formed states to make the Jewish communists appear as a transnational phenomenon to be feared not only by them but by the Western countries. If this danger was not stopped, so the argument went, the revolutionary wave led by Jews might sweep Western Europe as well. The Peace Conference in the end heeded the call and decided that there was a need to stem the Bolshevik tide. At the same time, minority protection in the peace treaties was an important new feature that was supposed to protect Jewish people as well, although the League of Nations, responsible to carry out such measures, came up way too short in this dimension-as in others. So, Jewish communities accused of incendiary activity remained the scapegoats, non-nationals, and dangerous, all this giving the basis to cut back on their rights. It is enough to think of the Numerus Clausus of 1920, the Hungarian law that discriminated against Jews mainly in higher education.

The second chapter of the book focuses on Germany under the Hitler era, and the increasing measures against the Jewish-Bolshevik enemy. As the author puts it, in Germany "Judeo-Bolshevism became a symbol of the need to wage a ruthless war of preemptive defense against racialized threats to national security." (92) The Spanish Civil War gave a perfect opportunity for Hitler to widen his vision to much of the European continent. Since he was already seen as a successful person against the imagined Judeo-Bolshevik danger, he easily became the credited leader of this fight internationally too. The Catholic Church called attention to the peril caused by both Communism and Nazism, but its own anti-Semitism before and during World War II proved to be a hindrance in case of the latter, and only in the postwar years did it start to speak out clearly against the totalitarian state form.

Naturally, the most tangible and brutal effort against the Judeo-Bolshevik peril was the German assault on the Soviet Union in the summer of 1941. Although the propaganda of ideology masked geopolitical goals, still it was by far the harshest manifestation of anti-Semitism and anti-Bolshevism of the past decades. At the same time, however, the old lurking fear of Asiatic hordes could be detected in most European countries that shared the belief that there was danger in the East, and this danger might be uprooted by the German preemptive strike. The Nazi atrocities on Soviet territory-practically genocide-were in close harmony with and a direct antecedent to the "final solution" to exterminate the Jews. But it was 
not only the Germans. On the territories under Soviet control in Poland in 193941, there were undoubtedly many cruelties carried out—and the Nazi propaganda did everything to tout them as to give some justification for the offensive in the East-, and almost everywhere among the "liberated" local population collective anti-Semitism burst open. The Germans allowed this type of safety valve to work: trying to turn the pent-up hatred against the Jews and Bolsheviks into a type of crusade. Then, as the Soviet Red Army began its counteroffensive and it became clear that Eastern Europe would belong to the Soviet sphere of influence, the antiJewish and anti-communist sentiment reached its zenith, and never disappeared.

With Eastern Europe becoming a Soviet zone after World War II, in certain countries the stereotype concerning Judeo-Bolshevism remained. Right after the conclusion of the most horrific war in human history, in Poland, Romania, and Hungary the well-known defensive reflexes were back at work. As a result, the overwhelming majority of the people in these countries considered the Soviet occupation-which was called "liberation" in the official propaganda-and the Moscow-centered rule of the local communist parties as the latest chapter of the Jewish-Bolshevik conspiracy. According to Hanebrink, this had three pillars: the behavior of the Soviet occupying troops, the reappearance of Jews-both physical and political, and the emergence of the earlier persecuted and banned communist parties via the effective help of the Soviet troops. And since again there were a few conspicuous Jewish leaders in these communist parties, the generalization and earlier acquired instincts gave potent basis for many to give credit for the JewishCommunist cooperation and their aim to rule the world. In the "us vs. them" dichotomy the Jewish population in these countries more often than not fell in the "them" category, "in ways that mapped neatly onto popular understandings of the new Soviet-backed state as a foreign power: 'them'." (175). After the establishment of the state of Israel in 1948, and when it became real that the new country enjoys American backing, there was a wave of nationalist communism in the satellite countries, which had again negative results for the Jewish citizens. They were once more targeted as aliens, and people perceived a Zionist conspiracy by the help of which the Jews wanted to grab control - to the disadvantage of their respective countries. Basically, the politics of memory was at stake, in which the Holocaust was committed by the Nazis and their collaborators, while liberation was thanked to the Soviets who worked together with the national antifascist elements. In this type of narrative there was little room for the Jews.

Another chapter concentrates on the processes regarding the central theme of the book-this time in West Germany, which was established in 1949. The larger, western part of Germany was under American, or Allied, control in the first years after the Second World War. In the changed political climate and under 
the American-sponsored denazification program there could be no promoting the known elements of the propaganda for a Judeo-Bolshevik conspiracy. The emphasis quickly, and with the setting in of the Cold War totally, shifted only to anti-communism. In this work, many former Nazis participated under American protection, because the experience and "changed" worldview of such people could be used by the United States. This somewhat new conservative Christian approach also appeared in Austria and basically everywhere in the western part of Europe: an ecumenical Christian (Democratic) Europe had to defend itself against the Asiatic communist ideology that denied the existence of God and tried to make the life of the Church close to impossible in its sphere. In addition, there was the fear of the totalitarian state that could feed on the memory of not-so-distant fascism and Nazism. That is how the Judeo-Christian idea came into being in the first half of the Cold War, which served as perhaps one of the most important theoretical theses of liberal democracy against the Soviet bloc.

The book's final chapter examines the thirty years since the end of the Soviet Union and communism in Eastern Europe. Its central theme is how the memory of the Holocaust became relative. This was done in many post-socialist countries by elevating the victims of the communist era onto the same level as the millions of Jews murdered by the Nazis. This almost automatically meant that often the Jews appeared as scapegoats for crimes in the 1945-1990 period. "Amid debates about how to strike the right balance between acknowledging the genocide of Europe's Jews and recalling other kinds of suffering — above all, suffering caused by the crimes of Communist regimes - the demands of Holocaust memory", writes Hanebrink, "were frequently juxtaposed with another form of collective memory: national memory." (259) Such debate, if not meaningless, is unnecessary. Both systems-Nazism and Communism-had left millions of people dead in their wake. The author implicates that the relative comparison between the two tragic state forms sprang from the latent, or sometimes quite open, anti-Semitism that could not tolerate that "only" Jews should be remembered as victims. Naturally, this type of politics of memory at the same time wants to alleviate the perhaps existing pangs of collective conscience that stems from the role of an accomplice in the systematic extermination of the Jews in these countries.

And the phenomenon has not disappeared without a trace in the present century. In his conclusion Hanebrink states-having in mind the mostly negative reactions to the immigrant and refugee wave coming to Europe from the Middle East and beyond - that "examining the ideological function that the idea of JudeoBolshevism has played in European politics since the end of World War I reveals that this myth - a potent fusion of racism and ideological defensiveness - is one of the most fertile sources for anti-Muslim and anti-Islamic sentiment today." (277) 
There are minor mistakes in the book. For instance, the author misses the German attack against France in World War II by a month, or the Hungarian foreign minister, Kálmán Kánya, appears as the prime minister of the country. (122, 131) This, at the same time, only indicates how difficult it is to write a monograph that encompasses a long period and many countries in Europe. Despite such minor shortcomings, the exhaustive research and rich source material, the logical argument and contextualization, the examination of certain basic connections all make Hanebrink's work a worthy piece of modern historiography. 